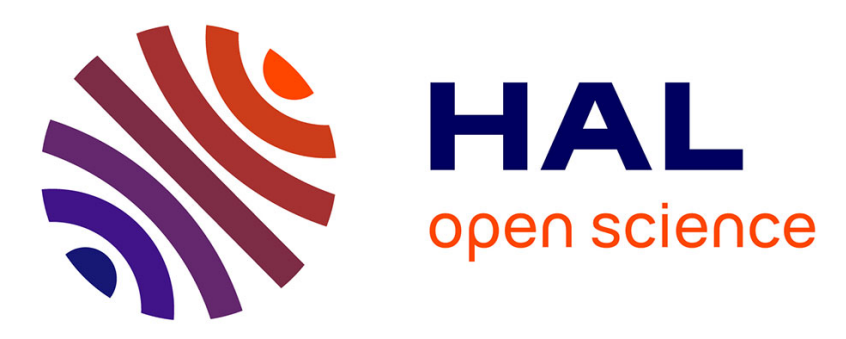

\title{
On differences in satellite wind products and their effects in estimating coastal upwelling processes in the south-east Pacific.
}

\author{
Marie Croquette, Gerard Eldin, Carmen Grados, Myrian Tamayo
}

\section{To cite this version:}

Marie Croquette, Gerard Eldin, Carmen Grados, Myrian Tamayo. On differences in satellite wind products and their effects in estimating coastal upwelling processes in the south-east Pacific.. Geophysical Research Letters, 2007, 34 (11), pp.L11608. 10.1029/2006GL027538 • hal-00280343

\section{HAL Id: hal-00280343 \\ https://hal.science/hal-00280343}

Submitted on 6 Apr 2021

HAL is a multi-disciplinary open access archive for the deposit and dissemination of scientific research documents, whether they are published or not. The documents may come from teaching and research institutions in France or abroad, or from public or private research centers.
L'archive ouverte pluridisciplinaire HAL, est destinée au dépôt et à la diffusion de documents scientifiques de niveau recherche, publiés ou non, émanant des établissements d'enseignement et de recherche français ou étrangers, des laboratoires publics ou privés. 


\title{
On differences in satellite wind products and their effects in estimating coastal upwelling processes in the south-east Pacific
}

\author{
Marie Croquette, ${ }^{1}$ Gérard Eldin, ${ }^{1}$ Carmen Grados, ${ }^{2}$ and Myrian Tamayo ${ }^{3}$ \\ Received 19 July 2006; revised 2 November 2006; accepted 6 February 2007; published 12 June 2007.
}

[1] Alongshore wind stress and curl obtained from ERS and QuikSCAT satellite wind products are routinely used to investigate coastal upwelling dynamics in the south-east Pacific. North of $17^{\circ} \mathrm{S}$ and south of $26^{\circ} \mathrm{S}$ there is a good agreement in the seasonal cycle of both products. Data from Peruvian coastal wind stations are used to validate satellite coastal winds. Between $17^{\circ} \mathrm{S}$ and $26^{\circ} \mathrm{S}$ seasonal cycles from coastal stations are in phase with QuikSCAT but in opposition with ERS. This discrepancy is confirmed during the overlapping period of the satellite products. Therefore, data from ERS do not seem to capture the strong cross-shore wind gradient in that area, while QuikSCAT renders at least part of it. These differences are dramatically enhanced when computing the wind stress curl along the coast: estimates of Ekman pumping obtained from QuikSCAT data in a coastal band are 2-3 times higher than those achieved with ERS data. Citation: Croquette, M., G. Eldin, C. Grados, and M. Tamayo (2007), On differences in satellite wind products and their effects in estimating coastal upwelling processes in the south-east Pacific, Geophys. Res. Lett., 34, L11608, doi:10.1029/2006GL027538.

\section{Introduction}

[2] Coastal upwelling in eastern boundaries current systems occurs when the wind stress has an equatorward alongshore component (Ekman transport) or a negative wind stress curl in the southern hemisphere (positive in the northern hemisphere) (Ekman suction). In the south-east Pacific (SEP) upwelling system, along the coasts of Peru and Chile, both mechanisms have been identified to influence upwelling variability. For instance, cross-shore current velocity estimated from a mooring at $15^{\circ} \mathrm{S}$ was found coherent with alongshore wind variations from a coastal wind station [Lentz, 1992]. In addition, Halpern [2002] has suggested that strong negative Ekman pumping may be the source of the deepened coastal thermocline at $15^{\circ} \mathrm{S}$ during the 1997-1998 El Niño.

[3] It is thus relevant to better quantify the relative importance of the two Ekman processes. Satellite data provide long times series of wind measurements and are appropriate for that purpose. Wind products are available from two main satellites covering different time-periods: ERS and QuikSCAT. They are routinely used by the

\footnotetext{
${ }^{1}$ Laboratoire d'Etudes en Géophysique en Océanographie Spatiales, CNRS, CNES, IRD, Université Paul Sabatier, Toulouse, France.

${ }^{2}$ Instituto del Mar del Perú, Lima, Perú.

${ }^{3}$ Direccion de Hidrografía y Navegación, Lima, Perú.
}

oceanographic community, but, because of their limited spatial resolution, their accuracy in reproducing alongshore wind and wind stress curl at the coast can still be questioned. In particular, satellite wind products are limited to a distance of $50 \mathrm{~km}$ (ERS) or $25 \mathrm{~km}$ (QuikSCAT) from the coast, while onshore-offshore wind gradients exist close to the coast. For example, in the California Current System, wind observations from moorings and aircraft measurements have shown that there is a drop off of the wind stress amplitude near the coast. This drop off and its position are more or less simulated by atmospheric models [Capet et al., 2004; Pickett and Paduan, 2003] whereas satellite winds are not as accurate in reproducing it. A wind gradient at the coast creates an Ekman suction which may be capable of generating upwelling larger than $10 \mathrm{~m} \mathrm{~d}^{-1}$ [Pickett and Paduan, 2003; Münchow, 2000]. In the SEP system, different alongshore wind speed seasonal cycles were found at Arica $\left(18.5^{\circ} \mathrm{S}\right)$, Iquique $\left(20.5^{\circ} \mathrm{S}\right)$ and Antofagasta $\left(23.5^{\circ} \mathrm{S}\right)$ between coastal stations and ERS data [e.g., Blanco et al., 2001]. Blanco et al. [2001] suggested that ERS data could not faithfully represent the wind seasonal cycle close to the coast. On the contrary, ERS data variations are in phase with coastal station data variations at Lengua de Vaca $\left(30.5^{\circ} \mathrm{S}\right)$ [Shaffer et al., 1999], even if the alongshore wind speed decreases between the last ERS data and the coastal station. A further study is thus needed to evaluate the ability of the satellites in measuring true alongshore coastal wind and wind stress curl all along the South American coast.

[4] ERS data is available over 1992-2000 and QuikSCAT data from 1999 to present. In this study, alongshore wind speeds, and wind stress curls are investigated from these 2 products along the Peru and Chile coasts and compared to some coastal wind stations. Section 2 provides more information on the wind products. In section 3, alongshore wind speed is investigated. Mean state and seasonal variations of the two satellites are described and compared to coastal wind stations and previous studies. Section 4 is dedicated to the wind stress curl.

\section{Data Sets and Methods}

\subsection{Gridded Satellite Data}

[5] ERS 1-2 scatterometer measurements have a $50 \mathrm{~km}$ spatial resolution and a $500 \mathrm{~km}$-wide swath. These satellites covered the global ocean in 3 days and operated from January 1991 to December 2000. QuikSCAT winds from Seawind scatterometer have better spatial and temporal resolutions, $25 \mathrm{~km}$ and one day global coverage, respectively. Simultaneous measurements from both satellites are available for about one year and a half (July 1999 to January 2001). Several wind products are built from swath data by 


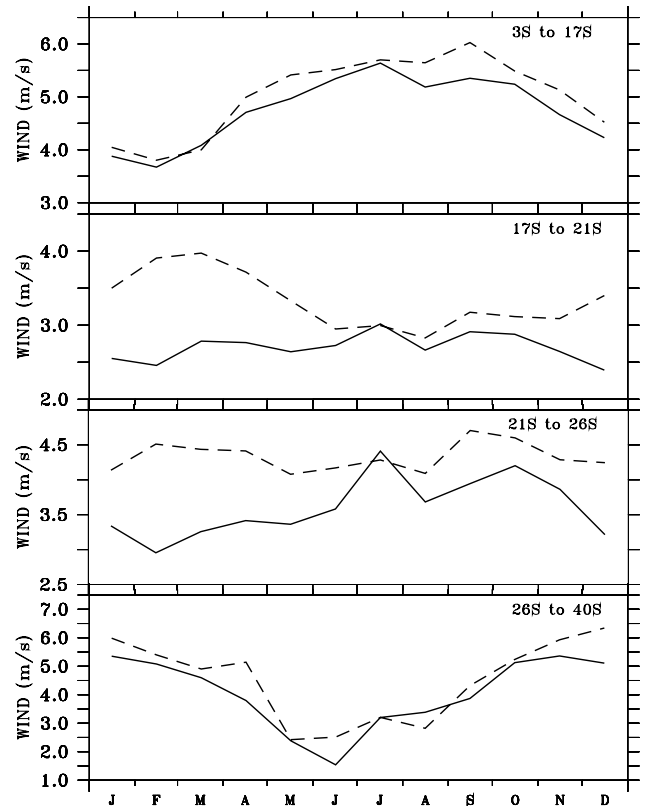

Figure 1. Alongshore wind speed seasonal cycle at the coast $(\mathrm{m} / \mathrm{s})$. The seasonal cycles were computed over different periods: ERS (full line) over 1991-2001 and QuikSCAT (dashed line) over 1999-2005.

different institutions, like PO.DAAC in the US (http:// podaac.jpl.nasa.gov). Products available from CERSAT www.ifremer.fr/cersat) are used in this study: ERS 1-degree and QuikSCAT 0.5-degree resolution grids, with weekly and daily temporal resolutions, respectively. These products are built with both ascending and descending passes. They are provided as representative of $10 \mathrm{~m}$ height winds. RMS differences between CERSAT products and offshore buoys wind speeds and directions are given as $1.5 \mathrm{~m} / \mathrm{s}$ and $17^{\circ}$ for QuikSCAT, and $1.38 \mathrm{~m} / \mathrm{s}$ and $24^{\circ}$ for ERS [Anonymous, 2002a, 2002b].

[6] For both products, the alongshore component is obtained by projection over a line parallel to the coast. Coastal values are obtained from the grid cell closest to the coast, around $50 \mathrm{~km}$ and $25 \mathrm{~km}$ for ERS and QuikSCAT respectively.

[7] Comparison between ERS 2 and QuikSCAT products in offshore areas for their common period shows a mean difference of $2 \mathrm{~m} / \mathrm{s}$ in speed and $20^{\circ}$ in direction and a correlation of 0.95 for wind speeds ranging from 3 to $20 \mathrm{~m} / \mathrm{s}$. The main discrepancies are found for low wind speed (less than $3 \mathrm{~m} / \mathrm{s}$ ) [Bentamy et al., 2000]. A computation over the whole south-east Pacific at a minimum distance of $300 \mathrm{~km}$ from the coast gives similar results.

\subsection{NAYLAMP Data}

[8] NAYLAMP (El Niño Anual Y Las Anomalías Medidas en el Pacífico) is an ocean observing project implemented by the Peruvian Navy through their Hydrographic Service (DHN). The project started in September 2001 and consists in 11 automatic meteorological coastal stations along the Peru coast. Among other parameters, they provide wind speed and direction every hour at a height of about $4 \mathrm{~m}$ above ground. More details on the
NAYLAMP project and on coastal wind data can be found at http://www.naylamp.dhn.mil.pe. Only some of these stations (Talara, $4.59^{\circ} \mathrm{S}$, Isla Lobos de Afuera, $6.93^{\circ} \mathrm{S}$, Chicama, $7.69^{\circ} \mathrm{S}$, San Juan, $15.34^{\circ} \mathrm{S}$, Matarani, $17.00^{\circ} \mathrm{S}$, and Ilo, $17.64^{\circ} \mathrm{S}$ ) will be used in this study because their 2 locations are free from possible obstructions (hills, buildings, etc.).

\section{Coastal Alongshore Wind Speed}

[9] A significant part of the variance in coastal upwelling processes is associated with synoptic wind variability associated with topographic features [Blanke et al., 2005], or propagation of coastal waves in the 5-10 days frequency band [Hormazabal et al., 2001]. However, the different temporal resolution of the ERS and QuikSCAT wind products do not allow a comparison in these frequency ranges, and our focus will be restricted to lower frequency variability, mainly the seasonal cycle.

\subsection{Satellite Winds Seasonal Cycles}

[10] Coastal alongshore wind speed seasonal cycles computed from ERS and QuikSCAT products after monthly averaging are compared in Figure 1. The studied area was divided into four regions, roughly corresponding to different seasonal cycles [e.g., Strub et al., 1998].

[11] North of the study area $\left(3^{\circ} \mathrm{S}-17^{\circ} \mathrm{S}\right)$, ERS and QuikSCAT seasonal cycles are in good agreement. The maximum alongshore speed occurs in austral winter $(5-6 \mathrm{~m} / \mathrm{s})$ and the minimum in summer $(3.5 \mathrm{~m} / \mathrm{s})$. Nevertheless the ERS maximum (July) leads the QuikSCAT maximum (September) by two months. A study of a 1991-1997 times series of ERS 1-degree coastal alongshore wind component had also shown a winter maximum [Shaffer et al., 1999].

[12] Between $17^{\circ} \mathrm{S}$ and $21^{\circ} \mathrm{S}$, ERS and QuikSCAT coastal seasonal cycles are different. ERS alongshore wind is quasi constant with only a slight maximum in austral winter $(3.6 \mathrm{~m} / \mathrm{s})$, whereas QuikSCAT winds show a clear maximum in austral summer $(3.8 \mathrm{~m} / \mathrm{s}, 1 \mathrm{~m} / \mathrm{s}$ above ERS data). The QuikSCAT maximum in austral summer at the coast is consistent with the seasonal cycle computed from a coastal station at $18.5^{\circ} \mathrm{S}$ [Blanco et al., 2001].

[13] Between $21^{\circ} \mathrm{S}$ and $26^{\circ} \mathrm{S}$, ERS speed is maximum in austral winter and minimum in austral summer. Although the QuikSCAT speed seasonal cycle is very weak, it shows a slight minimum in winter. For other seasons QuikSCAT data are most of the time $0.5-1 \mathrm{~m} / \mathrm{s}$ above ERS data. Blanco et al. [2001] had noted differences between ERS and a coastal station wind seasonal cycle at Antofagasta $\left(23.5^{\circ} \mathrm{S}\right)$. Wind speed was clearly maximum in summer and minimum in winter at that station. Thus, in this region, neither ERS nor QuikSCAT are consistent with wind data from a coastal station. However, the QuikSCAT seasonal cycle seems closer to what was observed at Antofagasta than to the ERS seasonal cycle. This seems to confirm a change in seasonal cycle from the coast to offshore, which origin is still to be investigated.

[14] In these two intermediate regions, the wind is particularly weak (note that all plots have different scales in Figure 1). However, the amplitude of the seasonal cycle is of $1.5 \mathrm{~m} / \mathrm{s}$ for QuikSCAT and is not negligible in regard of the mean values (around $3 \mathrm{~m} / \mathrm{s}$ ). Moreover QuikSCAT 


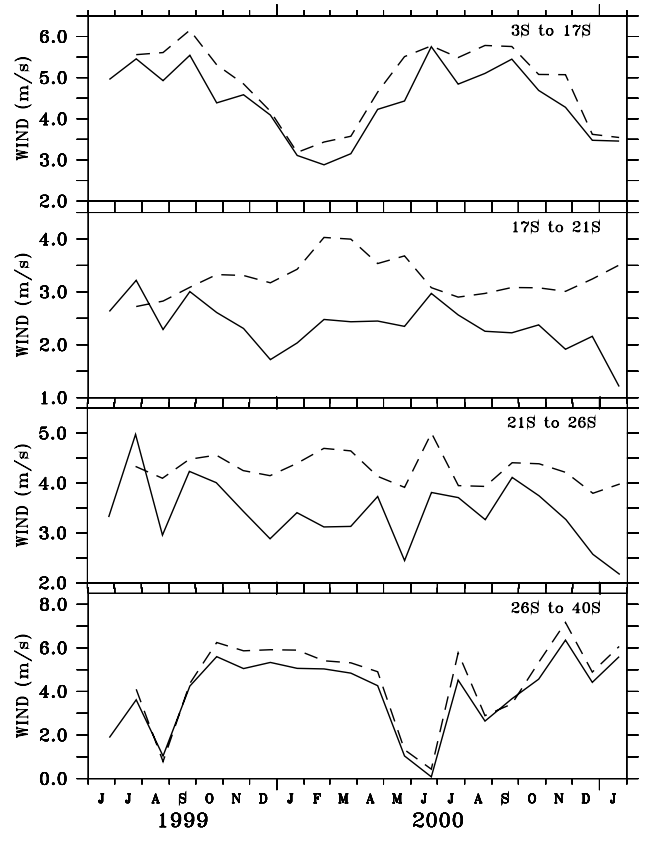

Figure 2. Monthly averaged alongshore wind speed at the coast over the ERS and QuikSCAT satellites overlapping period (1999-2001, m/s). ERS (full line) and QuikSCAT (dashed line).

coastal satellite winds are in agreement with the change in the wind seasonality toward the coast suggested by Blanco et al. [2001].

[15] Finally, south of $26^{\circ} \mathrm{S}$, the wind is stronger and the two products are in a better agreement. Wind cycles are characterized by a fall minimum and a spring-summer maximum as already shown by Shaffer et al. [1999]. A one month lag is notable between QuikSCAT minimum (in May) and ERS's (in June).

\subsection{Case of the $17^{\circ} \mathrm{S}-26^{\circ} \mathrm{S}$ Region}

[16] The alongshore wind seasonal cycles of ERS and QuikSCAT data are in agreement north of $17^{\circ} \mathrm{S}$ and south of $26^{\circ} \mathrm{S}$. In between, some significant differences are observed. Two main hypotheses may be invoked to explain this disagreement. Firstly, the seasonal cycles for the two data sets are computed over different periods of time, with a 1.5 -year overlap. Secondly, the two products have different temporal and spatial resolutions, with coastal QuikSCAT data being $25 \mathrm{~km}$ closer to the coast than coastal ERS data.

[17] Figure 2 presents ERS 2 and QuikSCAT time series for the same regions as in Figure 1, during the overlap period $(07 / 1999-01 / 2001)$. North of $17^{\circ} \mathrm{S}$ and south of $26^{\circ} \mathrm{S}$, variations are very similar and in agreement with previously described seasonal variations: in the north, maxima occur in winter of 1999 and 2000, and minima in summer of 2000 and 2001; in the south, both summer maxima and winter minima are evidenced in the 2 data sets. No lag in the peak occurrences is observed during this period between ERS 2 and QuikSCAT. Thus, the one (two) month lag previously observed, at the south (north), in the seasonal cycles maybe due to the different periods used to compute the seasonal cycles.
[18] In the intermediate regions, QuikSCAT and ERS coastal variations are very different. Between $17^{\circ} \mathrm{S}$ and $21^{\circ} \mathrm{S}$, QuikSCAT alongshore wind is maximum in summer 2000 and also starts to increase in January, beginning of summer 2001. ERS alongshore speed is minimum during November 1999-January 2000 and maximum during winter 1999 and 2000. Differences between the 2 data sets reach more than $1 \mathrm{~m} / \mathrm{s}$. and these different behaviors between ERS and QuikSCAT alongshore speeds are in agreement with the seasonal cycle of each wind product described in the previous section. Between $21^{\circ} \mathrm{S}$ and $26^{\circ} \mathrm{S}$, coastal ERS winds are very variable, on a monthly timescale. QuikSCAT alongshore wind speed is almost constant in the whole period with only a short maximum in June 1999. Here also these differences between the 2 data sets are consistent with their seasonal cycle differences.

[19] These observations during the overlap period confirm that the difference in seasonal cycles for the 2 data sets cannot be attributed to the different sampling time periods, and are more likely associated with an offshore-inshore wind gradient.

[20] Winds from NAYLAMP coastal stations can provide more information on that alleged wind gradient. Four stations are located in the first region $\left(3^{\circ} \mathrm{S}-17^{\circ} \mathrm{S}\right)$ and two in the northern part of the second region $\left(17^{\circ} \mathrm{S}-21^{\circ} \mathrm{S}\right)$. The anemometers are positioned at a few meters height above sealevel (4-6 m), whereas satellite products represent the 10-m wind. Since the anemometers elevations are not precisely known, no systematic correction on the wind amplitude can be made; for example, a value of $5 \mathrm{~m} / \mathrm{s}$ at $3 \mathrm{~m}$ height corrected with a simple logarithmic formula in neutral conditions would give an amplitude of $5.58 \mathrm{~m} / \mathrm{s}$ at 10 meters height in the offshore ocean. The direction is supposed to be constant with altitude. Because of that remaining uncertainty on amplitude, stress will be put on differences in seasonal cycles rather than on amplitudes. These data present a significant diurnal cycle, (see a summary in Table S1 of the auxiliary material), ${ }^{1}$ which could affect the comparison with satellite data, obtained at 6 A.M. and 6 P.M. local time passes. To prevent that potential bias, seasonal cycles (Figure 3) at Talara $\left(4.59^{\circ} \mathrm{S}\right)$, Lobos de Afuera $\left(6.93^{\circ} \mathrm{S}\right)$, Chicama $\left(7.69^{\circ} \mathrm{S}\right)$, San Juan $\left(15.34^{\circ} \mathrm{S}\right)$, Matarani $\left(17.00^{\circ} \mathrm{S}\right)$ and Ilo $\left(17.64^{\circ} \mathrm{S}\right)$ stations were computed from monthly averages using only data at 6 A.M. and 6 P.M. At Talara and Lobos de Afuera stations, the NAYLAMP and QuikSCAT data are in agreement with similar amplitudes and a minimum in summer. At Chicama, amplitude and seasonal cycle from satellite and coastal station are different: the coastal station shows a winter maximum whereas QuikSCAT wind is minimum and the amplitude differences vary from 1 to $2 \mathrm{~m} / \mathrm{s}$. At San Juan, both seasonal cycles are in agreement but amplitudes differ by about $1 \mathrm{~m} / \mathrm{s}$ in summer. In the intermediate region, at Matarani and Ilo, the seasonal cycle is characterized by a summer maximum and a winter minimum, in agreement with QuikSCAT alongshore wind seasonality. Thus, between $3^{\circ} \mathrm{S}$ and $18^{\circ} \mathrm{S}$, available coastal stations and QuikSCAT data present similar seasonal cycles, except at Chicama. In addition, in the south of the area, at Matarani and Ilo, there is a significant difference $(\sim 3$ and $2 \mathrm{~m} / \mathrm{s})$ between satellite and coastal data in winter. This wind

\footnotetext{
${ }^{1}$ Auxiliary material data set are available at ftp://ftp.agu.org/apend/gl/ 2006gl027538. Other auxiliary material files are in the HTML.
} 


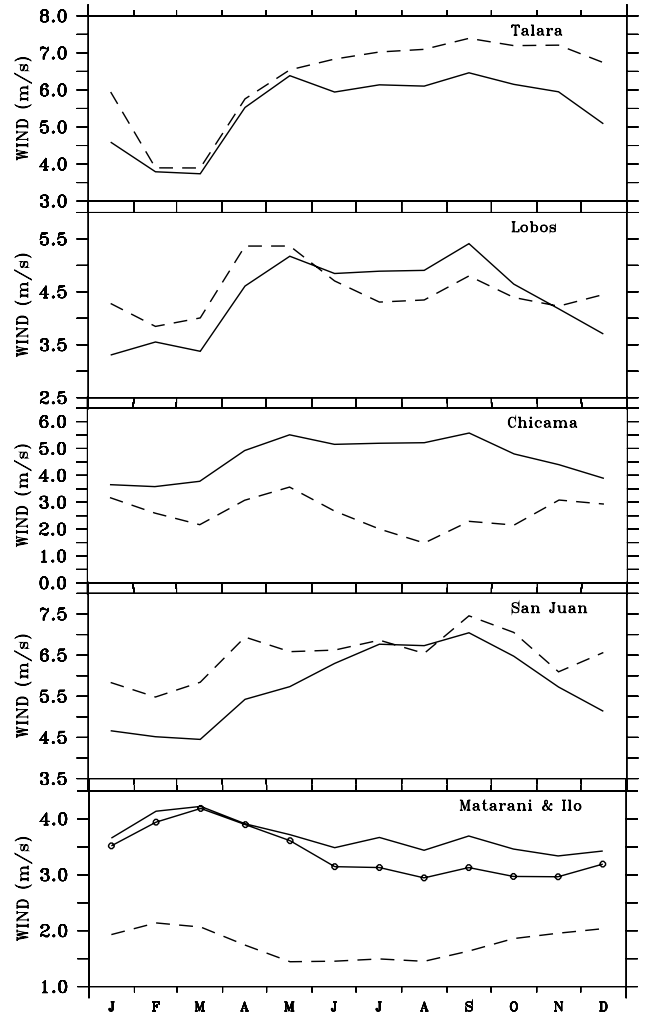

Figure 3. Coastal alongshore wind speed seasonal cycle computed over 2000-2004 with NAYLAMP data (full line) and QuikSCAT data (dashed line) at different locations. Bottom frame, two close stations are reported: Matarani (NAYLAMP, full line; QuikSCAT, dashed line) and Ilo (NAYLAMP, full line with dot marks).

gradient, if confirmed could induce significant Ekman pumping in the first $25 \mathrm{~km}$ from the coast.

\section{Wind Stress Curl}

\subsection{Mean State}

[21] Wind stress curl mean state is presented in Figure 4 for the QuikSCAT and ERS products. As expected, offshore, ERS and QuikSCAT exhibit similar wind stress curl magnitudes. Positive wind stress curl, reaching $1.210^{-7} \mathrm{~N} / \mathrm{m}^{2}$ is found south of $15^{\circ} \mathrm{S}$ where the oceanic south-east Pacific subtropical gyre is located. North of this latitude, the wind stress curl is negative with lower values $\left(0.510^{-7} \mathrm{~N} / \mathrm{m}^{2}\right)$ around $5^{\circ} \mathrm{S}$. Around the Galapagos Islands, weak values are obtained from the ERS product whereas strong wind stress curl values $\left(2.010^{-7} \mathrm{~N} / \mathrm{m}^{2}\right)$ can be found in the QuikSCAT product. In the near shore region, the two wind stress curl estimates are very different in amplitude, with strongly negative values for QuikSCAT data in a coastal band of about $100 \mathrm{~km}$ width: along the Peru coast and south of $30^{\circ} \mathrm{S}$, values under $-2.010^{-7} \mathrm{~N} / \mathrm{m}^{2}$ are estimated with QuikSCAT whereas ERS wind stress curl stays close to null; on average, coastal QuikSCAT curl amplitudes are from twice to four times stronger than ERS values. An area of positive wind stress curl can be noticed in the QuikSCAT mean around $4^{\circ} \mathrm{S}$ at the coast which does not appear in ERS data. As for alongshore wind amplitude, since both wind products show similar wind stress curl values offshore, discrepancies at the coast cannot be attributed to artefacts in the wind products. QuikSCAT data appear more appropriate than ERS data to represent the offshore-inshore wind gradients, although important differences with winds from coastal stations still persist locally.

\subsection{Seasonal Cycle}

[22] Wind stress curl seasonal snapshots (spring-summer and fall-winter) for ERS and QuikSCAT satellites are displayed in Figures S1a and S1b. As in the mean state, the two satellites seasonal cycles are similar offshore. North of the region, the wind stress curl is negative with higher amplitudes around $5^{\circ} \mathrm{S}$ during the whole year. South of $12^{\circ} \mathrm{S}$, in fall-winter, the wind stress curl is positive. This positive curl region moves south to $15^{\circ} \mathrm{S}$ in spring-summer. In this season, below the $15^{\circ} \mathrm{S}$ latitude, the wind stress curl is positive with stronger values south of $30^{\circ} \mathrm{S}$, nearer the coast. The wind stress curl displacement coincides with that of the south-east Pacific oceanic gyre.

[23] In the coastal region, QuikSCAT wind stress curl is negative all along the Peru and Chile coast and all year round except around Arica $\left(20.5^{\circ} \mathrm{S}\right)$ in summer. The wind stress curl maximum occurs in spring-summer at the Chilean southern coast, (values of $3.010^{-7} \mathrm{~N} / \mathrm{m}^{2}$ ). In fall-winter, the wind stress curl amplitude is maximum at the Peru coast and lower negative values extend to the North, to the equator. ERS satellite wind stress curl seasonality is less marked. South of the region, the wind stress curl is around 0 all year round and does not show any seasonal variations. Moreover local particularities appear in the QuikSCAT product which may reflect local coastal effects. For example, a wind stress curl maximum of $1.010^{-7} \mathrm{~N} / \mathrm{m}^{2}$ occurs around $25^{\circ} \mathrm{S}$ in
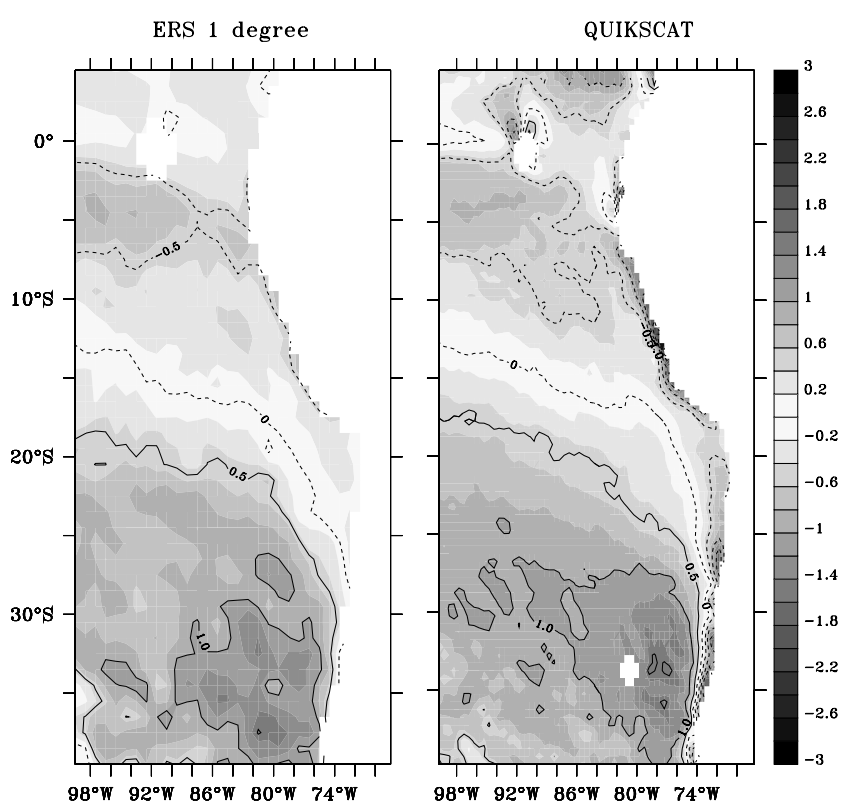

Figure 4. Mean wind stress curl in $10^{-7} \mathrm{~N} / \mathrm{m}^{2}$. The means were computed over different periods: (left) ERS over 1991-2001 and (right) QuikSCAT over 1999-2005. 
spring summer and around $4^{\circ} \mathrm{S}$ in fall-winter. These small scales features do not appear in ERS 1-degree product.

\section{Discussion and Conclusion}

[24] North of $17^{\circ} \mathrm{S}$ and south of $26^{\circ} \mathrm{S}$, the ERS and QuikSCAT data have the same alongshore wind speed seasonality. These seasonal cycles are in agreement with previous studies using coastal stations and ERS data. On the contrary, in the intermediate region, between $17^{\circ} \mathrm{S}$ and $26^{\circ} \mathrm{S}$, the alongshore wind is weaker and the two satellites present different seasonal cycles. ERS winds are maximum in winter/spring whereas QuikSCAT as well as winds from coastal stations are maximum in summer. A comparison of the overlapping times series over July 1999 - January 2001 has shown that this difference is not due to the different periods of satellite coverage. The ERS biases were previously noticed by Blanco et al. [2001] for a limited area around $23^{\circ} \mathrm{S}$ and are obviously due to the fact that ERS measurements stop too far from the coast. In this region, the alongshore wind seasonal cycle present an offshore-inshore gradient very near the coast.

[25] The wind stress curl of ERS 1-degree data shows very different amplitudes from QuikSCAT. The QuikSCAT wind stress curl is more than 3 times larger around $13^{\circ} \mathrm{S}$ and between $25^{\circ} \mathrm{S}$ and $34^{\circ} \mathrm{S}$ and is in agreement with Bakun and Nelson's [1991] climatology. The ERS 1-degree wind stress curl is weaker and even of different sign south of the region. This wrong representation of the wind stress curl is partly due to the low resolution of the product. In fact, using swath ERS data to build a higher resolution (0.5-degree) wind field using an objective interpolation scheme [De Mey and Ménard, 1989] leads to stronger estimates of wind stress curl (not shown). While offshore values are comparable with the ERS 1-degree curl, 2-3 times higher values are found at the coast along Peru and southern Chile. Actually, the mean QuikSCAT wind stress curl leads to an Ekman pumping of $0.5 \mathrm{~m} / \mathrm{d}$ at the northern region $\left(3^{\circ} \mathrm{S}-17^{\circ} \mathrm{S}\right)$ and weaker in the southern region (south of $26^{\circ} \mathrm{S}$ ). The Ekman transport occurs on a scale given by the Rossby radius [Allen, 1973; Pickett and Paduan, 2003], and an estimate of the associated velocity can be obtained by combining these 2 quantities. With this method, mean values of $1.77 \mathrm{~m} / \mathrm{d}$ to $2.4 \mathrm{~m} / \mathrm{d}$ are obtained in the Northern region $\left(3^{\circ} \mathrm{S}-17^{\circ} \mathrm{S}\right)$ and south of $26^{\circ} \mathrm{S}$.

[26] On average, Ekman transport thus leads to higher upwelling velocity than Ekman pumping. However, locally, pumping can reach values of $5 \mathrm{~m} / \mathrm{d}$ around $35^{\circ} \mathrm{S}$ and more than $10 \mathrm{~m} / \mathrm{d}$ around $4^{\circ} \mathrm{S}$ and can thus induce stronger upwelling than Ekman transport. Moreover in the Californian current, atmospheric modelling suggests that even QuikSCAT data resolution is not high enough to depict the wind stress drop off at the coast and the associated wind curl. Blending QuikSCAT offshore data with an atmospheric model has already led to a better SST simulation [Capet et al., 2004] because an atmospheric model better captures small scale coastal features in the alongshore wind. Assimilating satellite and coastal stations winds in a high resolution atmospheric model could be a way to improve the representation and the respective importance of Ekman transport and pumping processes in the SEP and other upwelling areas.

[27] Acknowledgment. The author(s) wish to acknowledge use of the Ferret program for analysis and graphics in this paper. Ferret is a product of NOAA's Pacific Marine Environmental Laboratory. (Information is available at http://ferret.pmel.noaa.gov/Ferret/)

\section{References}

Allen, J. S. (1973), Upwelling and coastal jets in a continuously stratified ocean, J. Phys. Oceanogr., 3, 245-257.

Anonymous (2002a), Mean wind fields (MWF product) user manual volume 1: ERS-1, ERS-2 \& NSCAT, Rep. C2-MUT-W-05-IF, CERSATIFREMER, Brest, France.

Anonymous (2002b), Mean wind fields (MWF product) user manual volume 1: QuikSCAT, Rep. C2-MUT-W-04-IF, CERSAT-IFREMER, Brest, France.

Bakun, A., and C. S. Nelson (1991), The seasonal cycle of wind stress curl in sub-tropical eastern boundary current region, J. Phys. Oceanogr., 21, $1815-1834$

Bentamy, A., E. Autret, P. Queffeulou, and Y. Quilfen (2000), Intercomparison of ERS-2 and QuikSCAT winds, in IEEE 2000 International Geoscience and Remote Sensing Symposium, vol. 1, pp. 234-236, IEEE Press, Piscataway, N. J.

Blanco, J. L., A. C. Thomas, M.-E. Carr, and P. T. Strub (2001), Seasonal climatology of hydrographic conditions in the upwelling region off northern Chile, J. Geophys. Res., 106, 11,451-11,467.

Blanke, B., S. Speich, A. Bentamy, C. Roy, and B. Sow (2005), Modeling the structure and variability of the southern Benguela upwelling using QuikSCAT forcing, J. Geophys. Res., 110, C07018, doi:10.1029/ 2004JC002529.

Capet, X. J., P. Marchesiello, and J. C. McWilliams (2004), Upwelling response to coastal wind profiles, Geophys. Res. Lett., 31, L13311, doi:10.1029/2004GL020123.

De Mey, P., and Y. Ménard (1989), Synoptic analysis and dynamical adjustment of GEOS-3 and Seasat altimeter eddy fields in the northwest Atlantic, J. Geophys. Res., 94, 6221-6231.

Halpern, D. (2002), Offshore Ekman transport and Ekman pumping off Peru during the 1997-1998 El Niño, Geophys. Res. Lett., 29(5), 1075, doi:10.1029/2001GL014097.

Hormazabal, S., G. Shaffer, J. Letelier, and O. Ulloa (2001), Local and remote forcing of sea surface temperature in the coastal upwelling system off Chile, J. Geophys. Res., 106, 16,657-16,672.

Lentz, S. J. (1992), The surface boundary layer in coastal upwelling regions, J. Phys. Oceanogr., 22, 1517-1539.

Münchow, A. (2000), Wind stress curl forcing of the coastal ocean near Point Concepcion, California, J. Phys. Oceanogr., 30, 1265-1280.

Pickett, M. H., and J. D. Paduan (2003), Ekman transport and pumping in the California Current based on the U.S. Navy's high-resolution atmospheric model (COAMPS), J. Geophys. Res., 108(C10), 3327, doi: 10.1029/2003JC001902.

Shaffer, G., S. Hormazabal, O. Pizarro, and S. Salinas (1999), Seasonal and interannual variability of currents and temperature off central Chile, J. Geophys. Res., 104, 29,951-29,961.

Strub, P. T., J. M. Mesias, V. Montecino, J. Ruttlant, and S. Salinas (1998), Coastal ocean circulation off western South America, in The Sea, vol. 11, edited by A. R. Robinson and K. H. Brink, pp. 273-313, John Wiley, Hoboken, N. J.

M. Croquette and G. Eldin, Laboratoire d'Etudes en Géophysique en Océanographie Spatiales, CNRS, CNES, IRD, Université Paul Sabatier, F-31400 Toulouse, France. (mariecroq@yahoo.fr)

C. Grados, Instituto del Mar del Perú, Esquina Gamarra y Gral Valle s/n, Chucuito, Callao, Casilla 22, Lima, Perú.

M. Tamayo, Direccion de Hidrografía y Navegación, Avenida Gamarra 500, Chucuito, Callao, Lima, Perú. 